\title{
Thermal regime of the Dnipro Reservoirs
}

\author{
Viktor Vyshnevskyi ${ }^{*}$, Serhii Shevchuk ${ }^{2}$ \\ ${ }^{1}$ National Aviation University, 1, Liubomyra Huzara Av., Kyiv, 03058, Ukraine. \\ ${ }^{2}$ Institute of Water Problems and Land Reclamation, 37, Vasylkivska Str., Kyiv, 03022, Ukraine. \\ * Corresponding author. Tel.: +380662322337. E-mail: vishnev.v@gmail.com
}

\begin{abstract}
Based on the results of regular monitoring and remote sensing data the patterns of water temperature of the reservoirs cascade on the Dnipro River were identified. A characteristic feature of the thermal regime of the Dnipro Cascade has been the water temperature increase over the past decades. In the period 1977-2020 the water temperature in summer increased by $0.74{ }^{\circ} \mathrm{C}$ decade $^{-1}$, and during May-October by $0.65{ }^{\circ} \mathrm{C} \mathrm{decade}^{-1}$. An important factor influencing the thermal regime of the reservoirs is the influence of those ones, located upstream. Water from them is discharged from the lower layer, where the processes of heating and cooling are very slow. This has a significant influence on the water temperature of downstream reservoirs, especially on their upper part. The water temperature in this part during spring and summer seasons is lower compared to natural conditions. In autumn it is higher. The temperature of water also depends on the latitude: it rises in the reservoirs located both downstream and to the south. Another important factor influencing the water temperature is the wind, which can change the temperature in the surface layer by $5-6{ }^{\circ} \mathrm{C}$. Water temperature also depends on the intensity of algae bloom - it is higher in the spots of a large bloom.
\end{abstract}

Keywords: Water temperature; The reservoirs cascade; The Dnipro River; Regular monitoring; Remote sensing data.

\section{INTRODUCTION}

The number of publications devoted to the study of water temperature of rivers, lakes and reservoirs, is very large. Nowadays, the changes caused by global warming are the most popular issue. Considering the long-term observations, many authors (Adrian et al., 2009; Austin and Colman, 2007; Czernecki and Ptak, 2018; Efremova et al., 2016; Filatov et al., 2014; Litvinov and Zakonnova, 2012; Marszelewski and Pius, 2016; Nowak et al., 2020; Ptak et al., 2018, 2020; Strutynska and Grebin, 2010; Vyshnevskyi, 2020a; Vyshnevskyi, 2020b; Vyshnevskyi and Shevchuk, 2020; Woolway et al., 2017) state that there is a trend of water temperature increase. This increase depends both on the location of a studied region and the period of observation. In many cases, the upward trend in temperature ranges from $0.3-0.6^{\circ} \mathrm{C}$ decade $^{-1}$ and can even reach $1.0^{\circ} \mathrm{C}$ decade $^{-1}$, as is the case with the Great Lakes (Austin and Colman, 2007). Another important aspect of the study is the effect of upstream reservoirs on tailwater temperature. Relevant studies (Meilutyte-Barauskiene et al., 2005) show decreased tailwater temperature in July and an increase in October. This impact significantly depends on the volume and depth of water bodies (Cheng et al., 2020; Wang et al., 2020).

There are many surface water temperature studies based on remote sensing data. The studies (Barsi et al., 2014; Sharaf et al., 2019) prove a strong correlation between measured and calculated data obtained using the Landsat 8 satellite. It was found that the use of thermal Band 10 of this satellite provides more reliable results compared to Band 11. A similar result, which demonstrates a good correlation between the measured data and those determined by the Landsat satellite, was obtained for the river affected by the reservoir (Zhao et al., 2020).

Despite a large amount of research in this area, the factors controlling spatial and temporal patterns of water temperature in large reservoirs that form a cascade are still not well understood. This concerns the largest reservoirs cascades in
Europe, i.e. the Volga and the Dnipro rivers. To date, there are research results based mainly on regular monitoring data. These data show the tendency to water temperature increase and, at the same time, reduce the duration of the ice cover (Vyshnevskyi, 2020a; Vyshnevskyi and Shevchuk, 2020). Spatio-temporal features of water temperature of reservoirs, in particular on the Dnipro River, have not been studied enough. In this case, an effective tool that can provide additional information about water temperature is remote sensing, which, however, can be limite $\mathrm{d}$ by clouds typical in the cold season.

In general, the water temperature in the reservoirs depends on many factors: the climatic conditions (global warming), the reservoirs size and their location. Another factor that affects water temperature is the water discharge from industrial facilities. In addition, there are some other influencing factors such as wind activity and algal bloom intensity. Thus, the main objective of this research is to understand and evaluate the thermal regime of the reservoirs cascade on the Dnipro River. These thermal regime features and patterns can be typical for the reservoirs cascades on other rivers. The important aspect of the study is the examine the factors impacting water temperature in the reservoir cascades.

\section{THE STUDY AREA}

The study area covers all six reservoirs of the Dnipro Cascade, which is the second largest by volume in Europe after the Volga Cascade. Their total design volume is $43.8 \mathrm{~km}^{3}$. The smallest reservoir among them is the Kanivske Reservoir, the largest is the Kakhovske one. The average length of the reservoirs is $100-150 \mathrm{~km}$, the Kakhovske one is over $200 \mathrm{~km}$ long. The average width of the reservoirs mainly is $10-15 \mathrm{~km}$. The largest width of the Kremenchutske and Kakhovske reservoirs exceeds $25 \mathrm{~km}$. The maximum depth of most reservoirs (except the Dniprovske one) is about $20 \mathrm{~m}$. The maximum depth of the Dniprovske Reservoir, which is the deepest, is about $60 \mathrm{~m}$ (Fig. 1). 


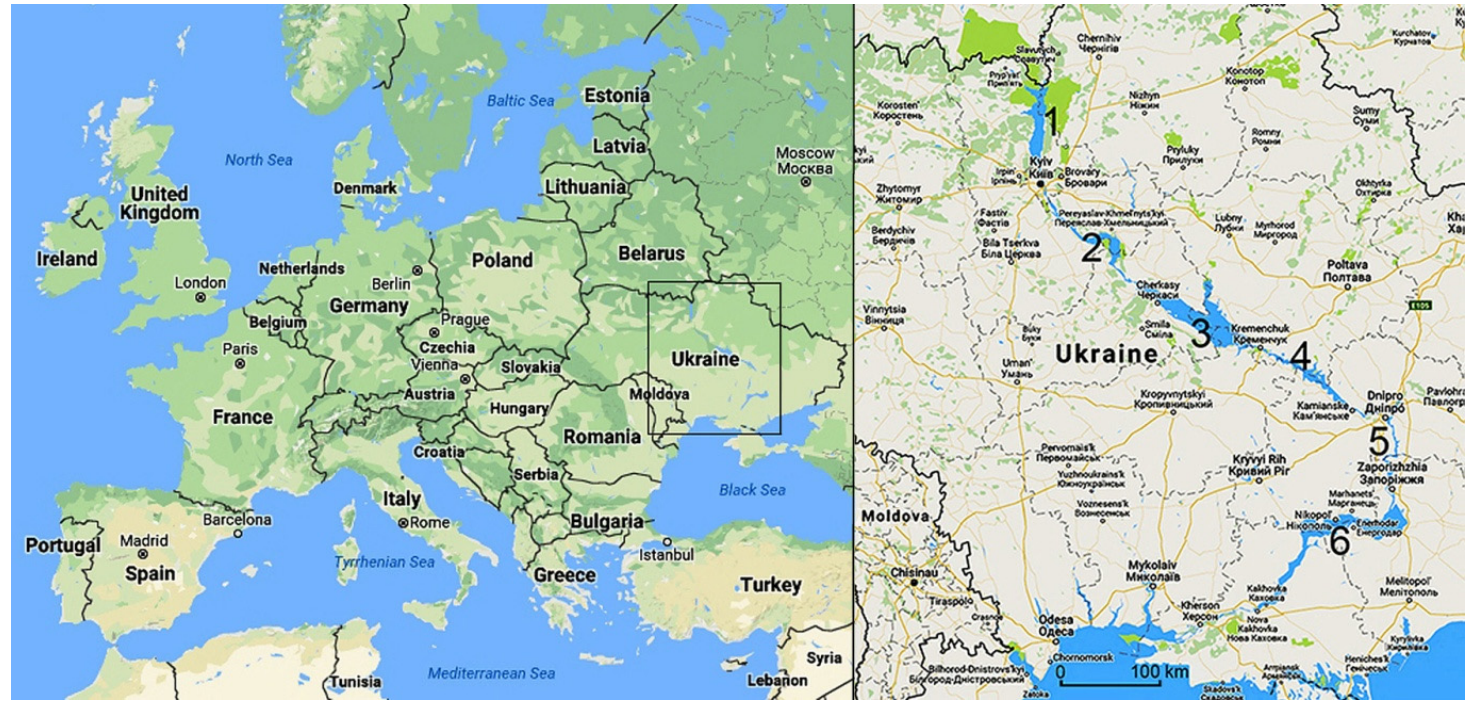

Fig. 1. The location of the Dnipro Reservoirs on the maps of Europe and Ukraine: 1 - Kyivske, 2 - Kanivske, 3 - Kremenchutske, 4 Kamianske, 5 - Dniprovske, 6 - Kakhovske.

In the 1930s, the construction of the Dnipro Cascade started from the Dniprovske Reservoir with the dam located in $\mathrm{Za}$ porizhzhia town. Then the Kakhovske (the 1950s), Kremenchutske, Kamianske, Kyivske reservoirs were constructed in the 1960s. The Kanivske Reservoir was constructed the last in the period 1972-1976.

Under natural conditions, before the construction of the reservoirs, the mean water runoff of the Dnipro River at its mouth was about $53 \mathrm{~km}^{3}$ per year. For the last decades, it has decreased by about $10 \mathrm{~km}^{3}$. Nowadays, the mean water runoff is almost equal to the total volume of the reservoirs. The decrease in water runoff is caused by the water intake for economic needs and extra evaporation from the water surface (from both the Dnipro Reservoirs and other water bodies located in the river basin). We can also assume the impact of global warming on the increase of evaporation from the river basin.

\section{METHODOLOGY AND DATA}

The main source of data for this research was the regular monitoring and remote sensing data. Many hydrological stations operate on the Dnipro Reservoirs: 6 - on Kyivske, 5 - on Kanivske, 7 - on Kremenchutske, 4 - on Kamianske, 6 - on Dniprovske and 8 ones on Kakhovkske. The regular observations at these stations are carried out daily at 8 a.m. and 8 p.m. local time. The longest observations (on Dniprovske and Kakhovske Reservoirs) started at the end of the 1950s, while the shortest ones (on Kanivske Reservoir) started in the second half of the 1970s. In most cases, the mean monthly data were used in our study for analysis.

The Kanivske and Kakhovske reservoirs were chosen as the main objects for the study of water temperature long-term changes. When studying the Kanivske Reservoir, the data from the hydrological station located in Kyiv city $(20 \mathrm{~km}$ downstream from Kyivska Hydroelectric Power Plant) were collected and analyzed. The measurement point in Kyiv is located on the left bank of the river facing southwest. Since the time of the construction of the Kanivske Reservoir, the temperature data have been analyzed for the period of 1977-2020. Nowadays, the average water velocity in cross-section near this station is about $0.2-0.3 \mathrm{~m} / \mathrm{sec}$; it is twice less than in its natural state. Another hydrological station where data was collected and analyzed was Nova Kakhovka. This station is located about 400 $\mathrm{km}$ south of Kyiv and about $860 \mathrm{~km}$ along the river. The station is located on the right bank of the Kakhovske Reservoir at a distance of $100 \mathrm{~m}$ from the dam. The reservoir shore near the measuring point faces east. There is almost no water flow near the point. Observations of the temperature there began in 1959.

The average monthly air temperature data from two nearby meteorological stations were also collected and analyzed. The meteorological station in Kyiv is located at a distance of $6 \mathrm{~km}$ from the hydrological station. The meteorological station Nova Kakhovka is located near the hydrological station at a distance of $200 \mathrm{~m}$.

Another meteorological parameter that was considered is the influence of wind - namely, its direction. Relevant data were collected from some meteorological stations located along with the Dnipro Cascade.

The study of spatial and temporal features of water temperature in the water area of reservoirs was also carried out using remote sensing data. The main source of data for determining the water surface temperature was images taken by the Landsat 8 satellite, launched in February 2013. The time interval between removals from this satellite is 16 days, and it is performed around noon. The spatial resolution of the satellite's thermal bands (B10 and B11) is $100 \mathrm{~m}$. The satellite images were downloaded from US Geological Survey website (www.glovis.usgs.gov).

In total, more than fifty satellite images were downloaded and analyzed. Conveniently, the Kyivske and Kanivske reservoirs are covered by one Landsat 8 satellite image, which has a range of $185 \mathrm{~km}$. The relevant study of the Kremenchutske Reservoir was conducted in relation to its main part, because different parts of this reservoir are observed on different days. The Kamianske Reservoir is almost completely covered by one satellite image. In the case of the Dniprovske and Kakhovske reservoirs, two satellite images obtained on the same day with a very small time difference were used to get the overall image.

The water surface temperature was determined based on B10 data, using ArcMap 10 program. The calculations were performed using the equation recommended by NASA: $\mathrm{t}=$ $(1321.08 /(\operatorname{Ln}((774.89 /((" L C 8$ B10.TIF" * 0.0003342) + 0.1) $)$ $+1)))-273.15$. This approach is rather common (Barsi et al., 
2014; Schaeffer et al., 2018; Sharaf et al., 2019). The reliability of the calculated and measured values was proved by the field study carried out on some water bodies, located within Kyiv city (Vyshnevskyi and Shevchuk, 2018).

The colour images showing the spatial distribution of water temperature were created to visualize temperature features. The territory that does not belong to the water area was identified using the calculation of the Normalized Difference Pond Index (NDPI). This index is calculated by the equation NDPI = $(\mathrm{B} 6-\mathrm{B} 3) /(\mathrm{B} 6+\mathrm{B} 3)$, in which $\mathrm{B} 3$ and $\mathrm{B} 6$ correspond to the channels of Landsat 8 satellite. Finally, the territory, not the water area, was presented in grey for better visualization (Vyshnevskyi, 2020b).

\section{RESULTS AND DISCUSSION \\ Long term changes in water temperature}

The water temperature in the Dnipro Reservoirs depends on many factors. One of them is seasonal fluctuations. The lowest water temperature in the upper reservoirs is observed in January, but in the Kakhovske Reservoir, located to the south, in February. Notably, in April and May, the water temperature near Kyiv is higher than it is near Nova Kakhovka town. Starting from June, the water temperature near Nova Kakhovka town becomes higher than it is near Kyiv. During the next three-four months, the difference in water temperature rises. In October and November, water temperature at Nova Kakhovka station is about $5{ }^{\circ} \mathrm{C}$ higher than it is at Kyiv station. In the winter period (actually from the end of November) the temperature difference becomes smaller (Fig. 2).

These features can be explained by the large volume of the reservoirs and the inertia of water mass in terms of heating and cooling. The additional factor is a water discharge from great depths of upstream reservoirs into the downstream ones. In most cases, these depths exceed $10 \mathrm{~m}$. Water heating at such large depths is usually very slow.

The available long-term monitoring data show that water temperature in the Dnipro Cascade tends to increase. The increase is observed all year round. It should be noted that this increase depends on the observation period and the location of the hydrological stations. Over the last three to four decades, the rise in temperature has been greater than in the period since the 1950 s or 1960s. In the period 1977-2020, the increase in water temperature at Kyiv station in May was $0.50{ }^{\circ} \mathrm{C}$ decade $^{-1}$, in June $0.71{ }^{\circ} \mathrm{C}$ decade $^{-1}$, in July $0.74{ }^{\circ} \mathrm{C}$ decade $^{-1}$, in August $0.85{ }^{\circ} \mathrm{C}$ decade $^{-1}$, in September $0.72{ }^{\circ} \mathrm{C}$ decade $^{-1}$ and in October $0.59{ }^{\circ} \mathrm{C}$ decade $^{-1}$. The average increase for the summer period is $0.74{ }^{\circ} \mathrm{C}$ decade $^{-1}$, for the period May-October $0.67{ }^{\circ} \mathrm{C}$ decade $^{-1}$. At the same time, the increase in water temperature at Nova Kakhovka station in May is $0.59{ }^{\circ} \mathrm{C}$ decade $^{-1}$, in June $0.84{ }^{\circ} \mathrm{C}$ decade ${ }^{-1}$, in July $0.64{ }^{\circ} \mathrm{C}$ decade $^{-1}$, in August $0.74{ }^{\circ} \mathrm{C}$ decade $^{-1}$, in September $0.56{ }^{\circ} \mathrm{C}$ decade $^{-1}$ and in October 0,38 ${ }^{\circ} \mathrm{C}$ decade $^{-1}$. The average growth during the summer period is $0.74{ }^{\circ} \mathrm{C}$ decade ${ }^{-1}$, in May-October $0.62{ }^{\circ} \mathrm{C}$ decade $^{-1}$.

So, it can be seen that the increase in temperature at both stations in summer period and in the period of May-October is almost the same (Fig. 3).

Fig. 3 shows that, despite the large distance between the hydrological stations, there is a reasonably good correlation between the monthly average values. The largest difference in temperature was observed in 2015, when the water runoff of the Dnipro River was extremely small - in fact, the smallest during the period of the Dnipro Cascade existence. As a result, in that year, the water exchange at Kyiv station became much

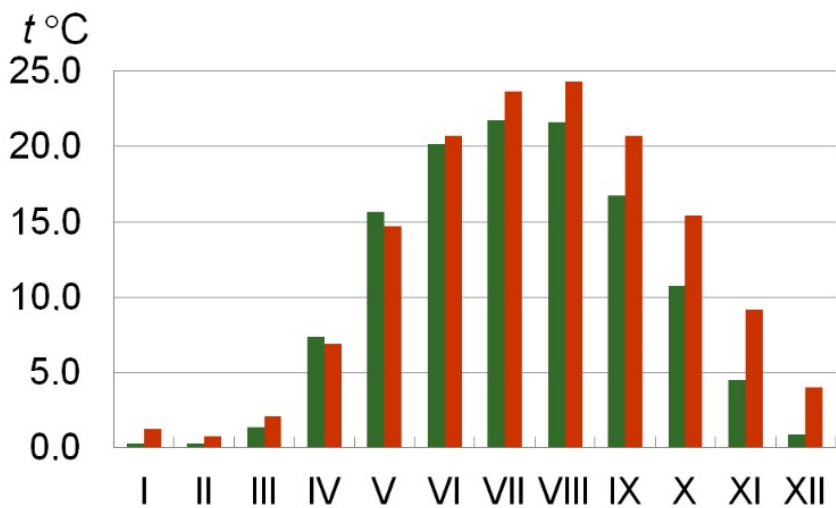

Fig. 2. Average monthly water temperature at hydrological stations of Kyiv (left column) and Nova Kakhovka (right column) during 1977-2020.

smaller than usual. In these conditions, the water in the warm period became warmer. To some extent it concerns all the last years, when water runoff was rather small (Fig. 4).

Fig. 4 shows that during the observation period water temperature in the reservoirs increased by $2-3{ }^{\circ} \mathrm{C}$. These data are generally consistent with data from water bodies in Europe (Adrian at al., 2009; Czernecki and Ptak 2018; Lieberherr and Wunderle, 2018; Ptak et al., 2020; Woolway et al., 2017).

The observed increase in water temperature, in general, corresponds to the increase in air temperature, but it is a bit smaller than air temperature increase. In the period 1977-2020, the increase in mean air temperature in the summer season at Kyiv meteorological station was $0.86{ }^{\circ} \mathrm{C}$ decade $^{-1}$, during the period of May-October $0.67^{\circ} \mathrm{C}$ decade $^{-1}$. The corresponding increase at Nova Kakhovka station was practically the same: 0.84 and $0.69{ }^{\circ} \mathrm{C}$ decade $^{-1}$, respectively (Fig. 5).

In our opinion, one of the reasons for this difference is the orientation of the reservoir shore near measurement points in relation to the parts of the world. As it was mentioned earlier, the reservoir shore at the site of the gauging station in Kyiv is slightly oriented to the south, at the Nova Kakhovka station - to the east. It should be added that a higher water temperature than air temperature is common, except in spring. The difference in average annual temperature that exceeds $2{ }^{\circ} \mathrm{C}$ was obtained in the study (Ptak et al., 2020), carried out on the lake in the North of Poland. In the latter case, this is due to the fact that the air temperature in winter can fall below $0{ }^{\circ} \mathrm{C}$ and the water temperature has a lower limit of $0{ }^{\circ} \mathrm{C}$.

The ratio between the average monthly water and air temperature during the year is not constant. The maximum correlation at Kyiv station is observed in July $(r=0.94)$ and in August $(r=0.92)$.

To some extent such strong dependence can be explained by the small variability of weather and relatively stable water runoff during this period of the year. In the spring period, the correlation is rather weak. During this period, the air temperature rises faster than water temperature. In addition, at this time, the water runoff is also quite variable. In autumn, especially in October, the air temperature drops more than the water temperature. The ratio between the average monthly water and air temperature at Nova Kakhovka station is generally similar. The strongest correlation is observed in June $(r=0.90)$, July $(r=$ $0.88)$ and August $(r=0.87)$. The correlation between water and air temperature during the six warmest months from May to October is much stronger than the average monthly values: the correlation coefficient at Kyiv station is 0.96 and at Nova Kakhovka station -0.92 . 

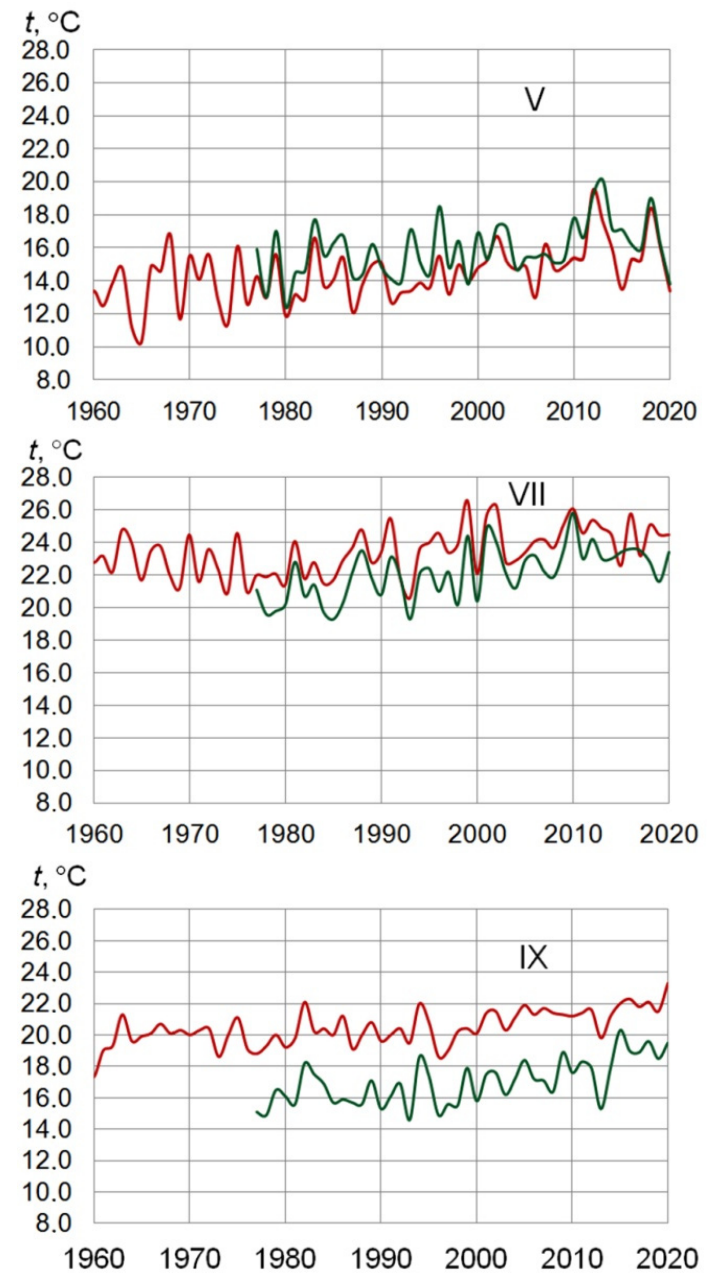
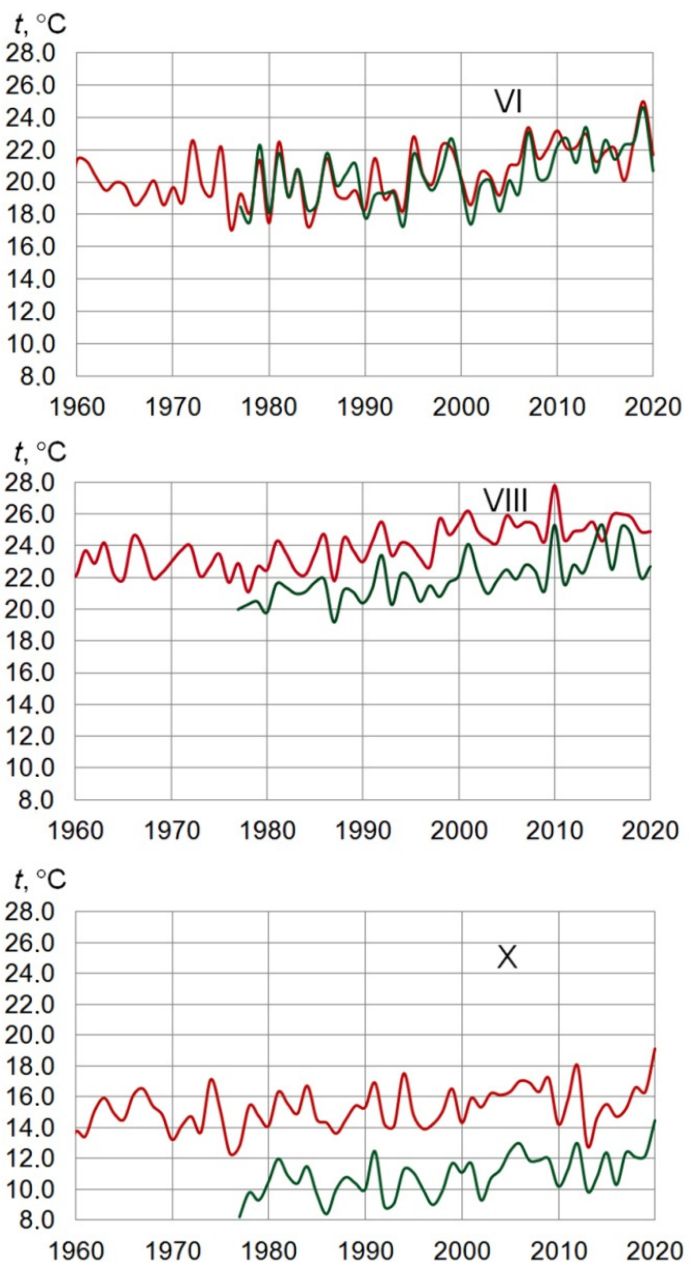

Fig. 3. The long-term changes in water temperature at Kyiv (green line) and Nova Kakhovka (red line) hydrological stations.

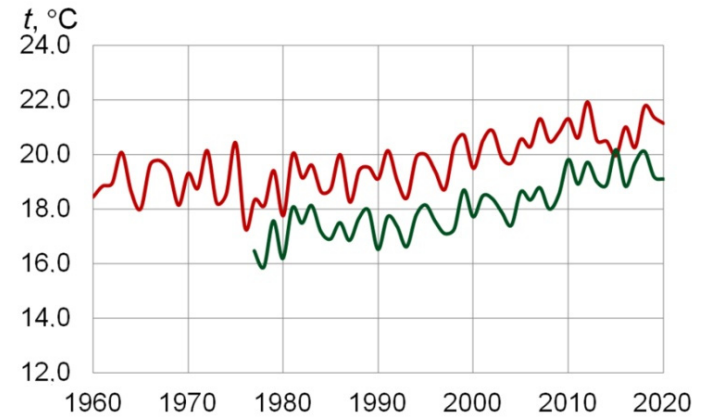

Fig. 4. The long-term changes in water temperature at hydrological stations Kyiv (green line) and Nova Kakhovka (red line) in the period of May - October.

\section{Water temperature in different reservoirs Kyivske Reservoir}

This reservoir is the northernmost among the others on the cascade. That is why the water temperature in it is the lowest. During the observation period, which started in the 1960s, the highest temperature is observed in July $\left(21.5-22.0^{\circ} \mathrm{C}\right)$ and in August $\left(21.0-21.5^{\circ} \mathrm{C}\right)$. The distinctive feature of this reservoir is the lack of influence of other reservoirs located upstream. It means that the thermal regime mostly depends on air temperature and water runoff of the Upper Dnipro River and the Pripyat River, which flow into the northern part of the reservoir.

In winter, the Kyivske Reservoir is usually covered with ice.
The essential increase in water temperature starts in April along with the spring flood on the Pripyat River, flowing into the reservoir from the northwest. A little later, the spring flood starts in the Upper Dnipro River, flowing into the reservoir from the north. One more important factor influencing the water temperature increase is the small depth of the northern part of the reservoir. As a result, the reservoir begins to warm up, starting from its northern and shallow part. At the same time, in the southern part of the reservoir, near the dam, the water temperature is the lowest (Fig. 6).

Water temperature in the reservoir in the summer period is rather homogenous and mostly depends on weather conditions, in particular of wind activity. In many cases, wind can cause a change in water temperature by $3-5^{\circ} \mathrm{C}$. This, in particular, can be seen in the example of the conditions of August 17, 2017, when the wind was observed from the east. In autumn, the decrease in water temperature begins with the shallow northeastern part of the reservoir. At the same time, there is the influence of the Pripyat River, in which water temperature is higher. The ice formation also begins from the northeastern part of the reservoir (Vyshnevskyi and Shevchuk, 2020). In autumn, the warmest water is observed in the deep part of the reservoir near the dam.

These results correspond to the data of regular monitoring. Thus, the water temperature at Dniprovske station, located in the extreme northeastern part of the reservoir, in April is about $1.5{ }^{\circ} \mathrm{C}$ higher than at Vyshhorod station, located near the dam. In October, the water temperature near the dam is about $2{ }^{\circ} \mathrm{C}$ higher than at Dniprovske station. 

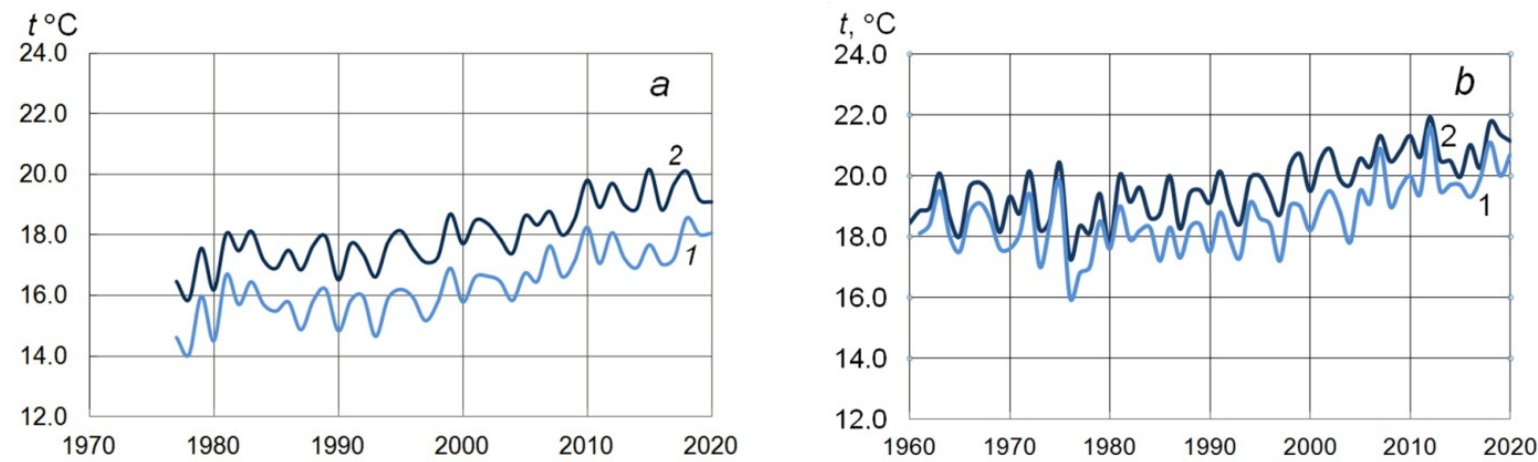

Fig. 5. The changes in air (1) and water (2) temperature near Kyiv $(a)$ and Nova Kakhovka town $(b)$ during a long-term period of observation (May - October).
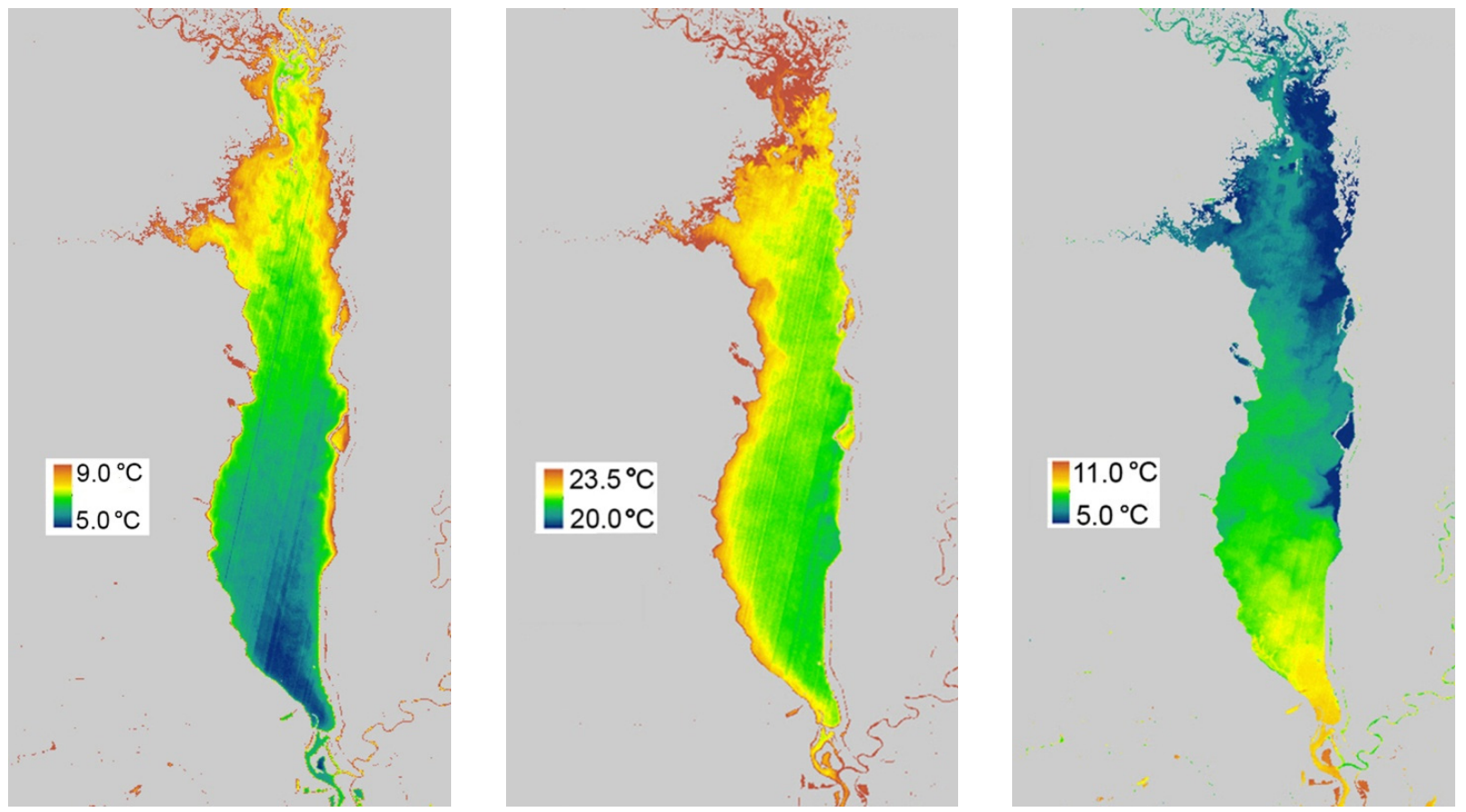

Fig. 6. The water temperature in the surface layer of the Kyivske Reservoir: on the left - on 21.04.2019, in the centre - on 17.08.2017, on the right - on 15.10.2015.

\section{Kanivske Reservoir}

This reservoir is the first to be affected by the other one located upstream. Another feature of this reservoir is its location to the south compared to the Kyivske Reservoir. There is a particular influence of the city of Kyiv on this reservoir. This impact becomes the largest in the cold period. The main reason for this influence is the operation of some enterprises, that discharge heated water into the reservoir. First of all it concerns Kyivska Thermal Power Plant № 5 (TPP-5), which operates in the southern part of the city. The daily amount of water used in the technological process is about 800 thousand cubic meters. Also important is the impact of Bortnitska Aeration Station, which purifies the city wastewater. The water discharge of this water treatment station is $700-750$ thousand cubic meters per day. The temperature of the treated wastewater discharged into the Dnipro River (the Kanivske Reservoir) is higher than it is in natural conditions. As a result, the water temperature in the Kanivske Reservoir is higher than in the Kyivske one, located upstream, especially in the cold period.
The remote sensing data enable us to analyze water temperature in all water area of the Kanivske Reservoir. In winter, the influence of the upstream Kyivske Reservoir causes the formation of an ice-hole in part located downstream from HPP. The Kyivske Reservoir influences the water temperature in the Kanivske one (mostly on its upper part) in other seasons as well. In many cases, the highest temperature in the second half of spring is observed in its central part. At this time, there is a significant influence of discharges of cold water from the bottom layer of the Kyivske reservoir. The water temperature in the deep south-eastern part of the Kanivske Reservoir remains cold due to the slow heating of a large water mass. The available data of the regular monitoring prove these features. In general, the water temperature in the upper part of the Kanivske Reservoir in the period from April to August is lower than in its south-eastern wide part. Starting from September, this upper and narrow part becomes warmer than that of the south. It can be explained by the water discharge from the great depths of the Kyivske Reservoir into the downstream, where the heat, accumulated during the summer, is stored until the autumn period (Fig. 7). 

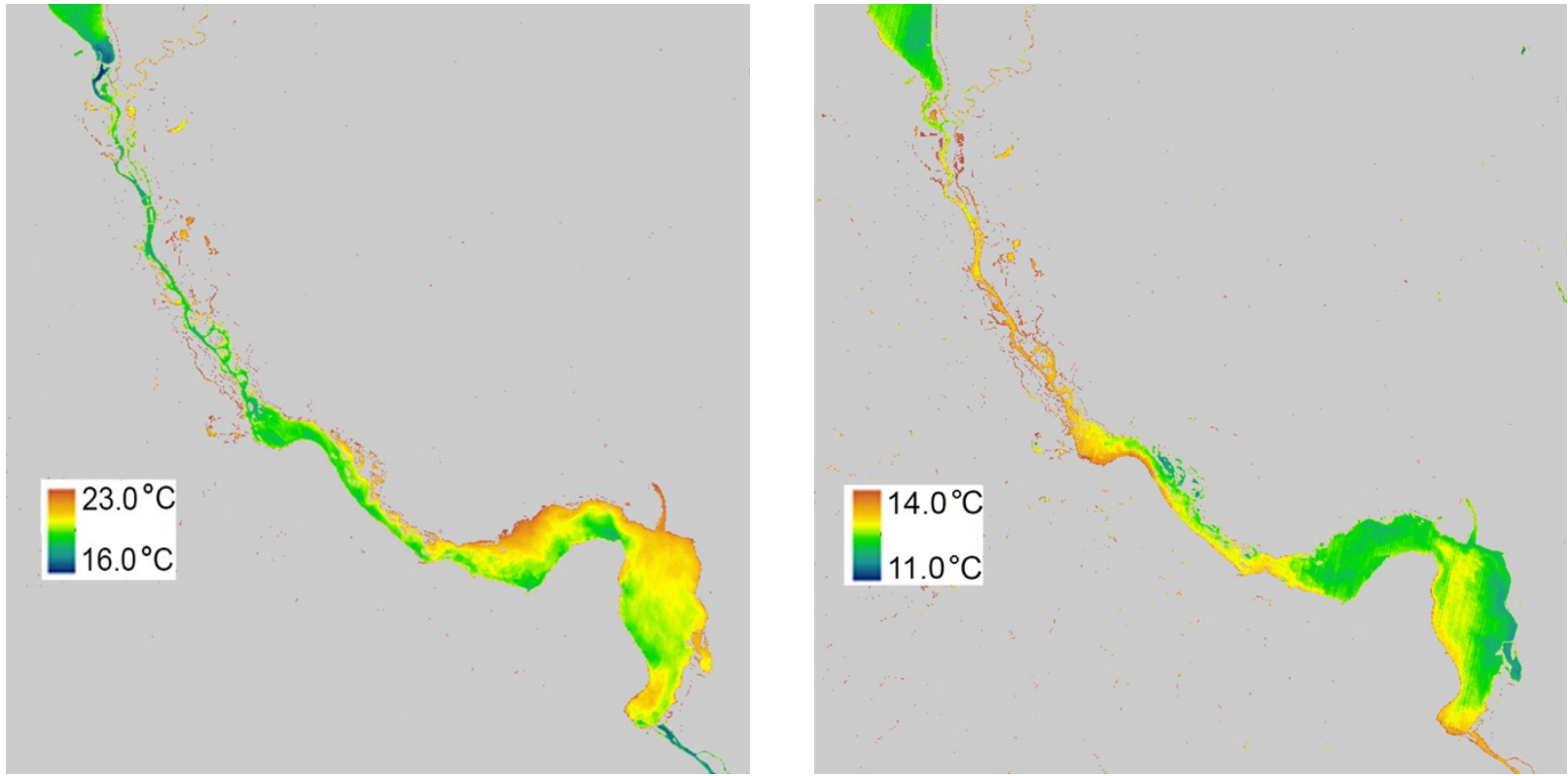

Fig. 7. The water temperature in the surface layer of the Kanivske Reservoir: on the left - dated 24.05.2015, on the right - dated 07.10.2018.
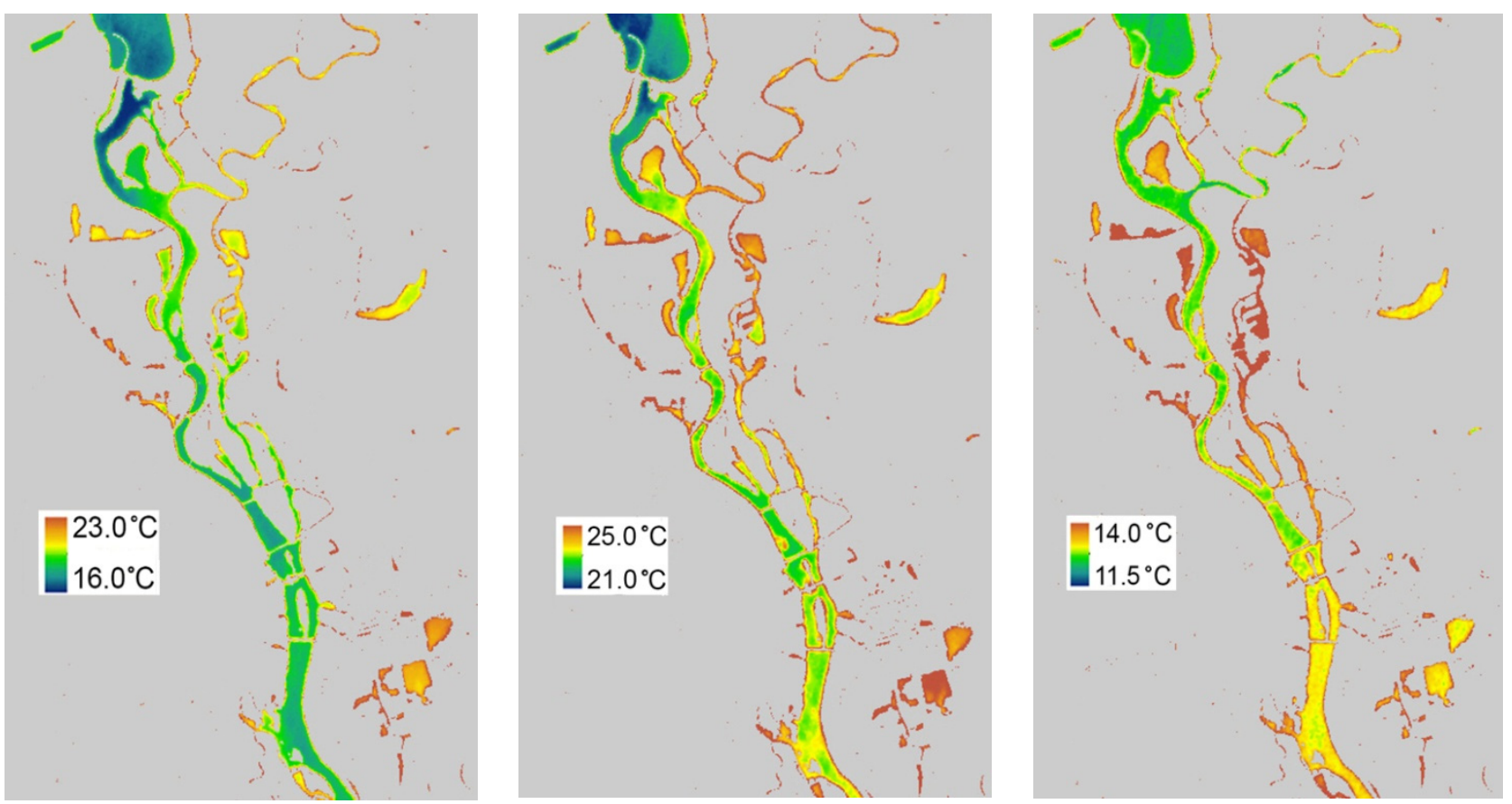

Fig. 8. The water temperature of the upper part of the Kanivske Reservoir near Kyiv: on the left - dated 24.05.2015, in the centre - dated 29.07.2016, on the right - dated 07.10.2018.

The local features of the upper part of the Kanivske Reservoir are more visible in large scale images. The lowest water temperature in spring is observed in the main branch of the Dnipro River, which the Kyivske Reservoir heavily influences. The water temperature in the Desna River (left tributary of the Dnipro River), bays and urban lakes of Kyiv is higher than it is in the main branch of the Dnipro River. The greatest difference in water temperature in the area downstream of Kyivska HPP and in the urban lakes is observed in the second part of May, when it can reach $5{ }^{\circ} \mathrm{C}$ (Fig. 8).

The irregular operation of Kyivska HPP causes the alternation of water masses in the Kyivske Reservoir and the Desna River. The water temperature in the Desna River in May - July is higher than in the main branch of the Dnipro River.
The spatial differences in water temperature start to change in the upper part of the Kanivske Reservoir during the onset of the autumn period (mainly from October). At this time, the water in the Desna River becomes colder than in the Dnipro River. Simultaneously, the temperature in the deep bays, which were artificially deepened (some of them has a depth more than $20 \mathrm{~m}$ ), also becomes higher. Therefore, we can assume that in these bays, there is a discharge of groundwater.

In the cold season the impact of industrial enterprises becomes noticeable. It concerns not only those located in Kyiv, but Trypilska TPP, located on the right bank of the reservoir $40 \mathrm{~km}$ south of this city. A plume of warm water, discharged from the TPP, can be seen at a distance of more than $10 \mathrm{~km}$ downstream (Fig. 9). 


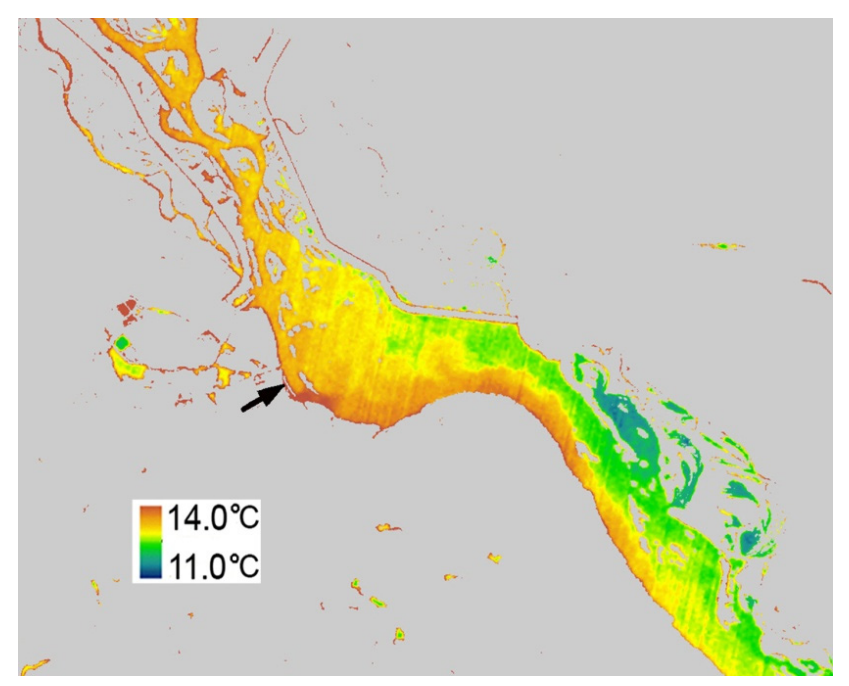

Fig. 9. The impact of Trypilska TPP operation (shown by arrow) on the adjacent part of the Kanivske Reservoir, dated 07.10.2018.

\section{Kremenchutske Reservoir}

This reservoir is the second by volume in the Dnipro Cascade. Its water volume $\left(13.5 \mathrm{~km}^{3}\right)$ is more than twice larger than the total volume of the two above mentioned reservoirs, and this fact has an essential influence on the water temperature in this reservoir.

During the observation period started in the 1960s, the mean water temperature at local hydrological stations in July and August is $22.0-23.0^{\circ} \mathrm{C}$, in September, it is $17.0-18.0^{\circ} \mathrm{C}$.

The Kremenchutske Reservoir, as well as the previous one, is influenced by the reservoirs located upstream. It means that in spring, the water temperature in its upper part is rather low. At this time, low water temperature is also observed in the deep southerneastern part of the reservoir. The highest temperature in the second part of spring is observed in the central part of the reservoir and in its shallow bays. The largest one among them is the Sula Bay, which is a drowned lower reach of the Sula River (Fig. 10).

In summer, the water temperature in the surface layer of the reservoir becomes rather homogenous. In the south-eastern part, it is a little bit higher than it is in the north-western part. The main reason for that is the influence of wind, which has the largest recurrence from the northwest. In July and August, the recurrence of this wind reaches $25 \%$. In the autumn season, the highest water temperature is observed in the deep south-eastern part of the reservoir. In October, the water temperature near Kremenchuk town is $1.0-1.5^{\circ} \mathrm{C}$ higher than it is in the northwestern part of the reservoir.

It can be added, that the Kremenchutske Reservoir, like those located downstream, is characterized by a rather intense algal bloom in the warm period (Vyshnevsky, 2020a). One of the reasons for this phenomenon is the high concentration of nutrients. The algal bloom, which is the highest in the period from July till September, has an influence on water heating and vice versa. In fact, during this period, the areas of the highest water temperature and maximal algal concentration often coincide. The main reason of this phenomenon is the decrease of water transparency in the spots of algal bloom (Kopylov et al., 2012). As a result, the heat from the Sun is absorbed by the smaller water layer. Moreover, water with algal cells is darker than clear ones. That is why the spots with high concentration of algal cells become warmer (Fig. 11).

\section{Kamianske Reservoir}

This reservoir is much smaller than the Kremenchutske and is significantly influenced by the latter one. In the second half of spring, the highest temperature is observed in the central part of the reservoir and in the shallow bays near both banks of the reservoir. The highest water temperature in the summer season is typically observed in the south-eastern part of the reservoir, mainly in the bays (Fig. 12).

During the observation period, started in the 1960s, the mean water temperature at local hydrological stations in July and August is $22.0-23.0^{\circ} \mathrm{C}$, in September it is $18.0-19.0^{\circ} \mathrm{C}$.

The characteristic feature of the Kamianske Reservoir is the significant influence of wind activity and algal bloom on the temperature distributions over the water area. The domination of north-eastern wind over the reservoir during the summer season causes the formation of the areas of the highest temperature and the most intensive algal bloom near the south-western right bank of the reservoir. In fact, the intensive algal bloom is also observed in September. It is proved not only by the view of the water surface, but by the results of the measurement at the water intakes, located on the reservoir (Fig. 13).
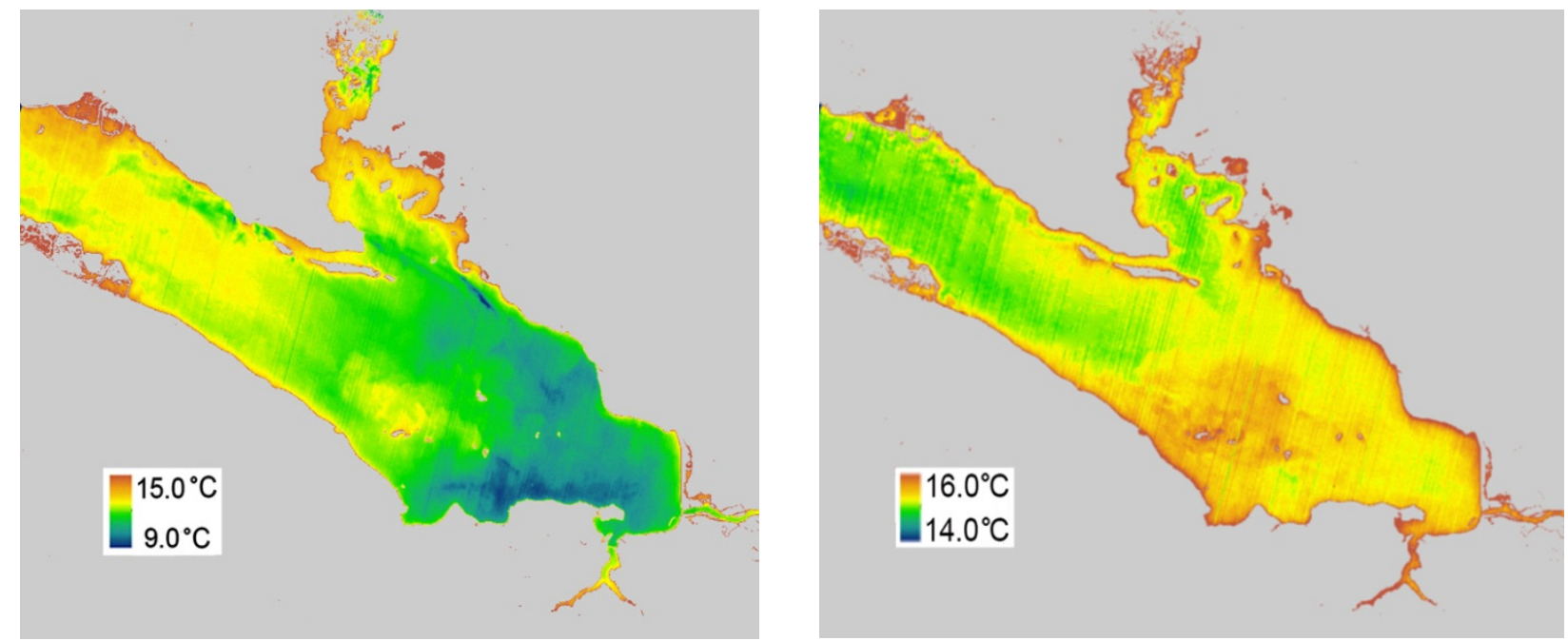

Fig. 10. The water temperature in the surface layer of the Kremenchutske Reservoir: on the left - dated 05.05.2019, on the right - dated 14.10.2020. 

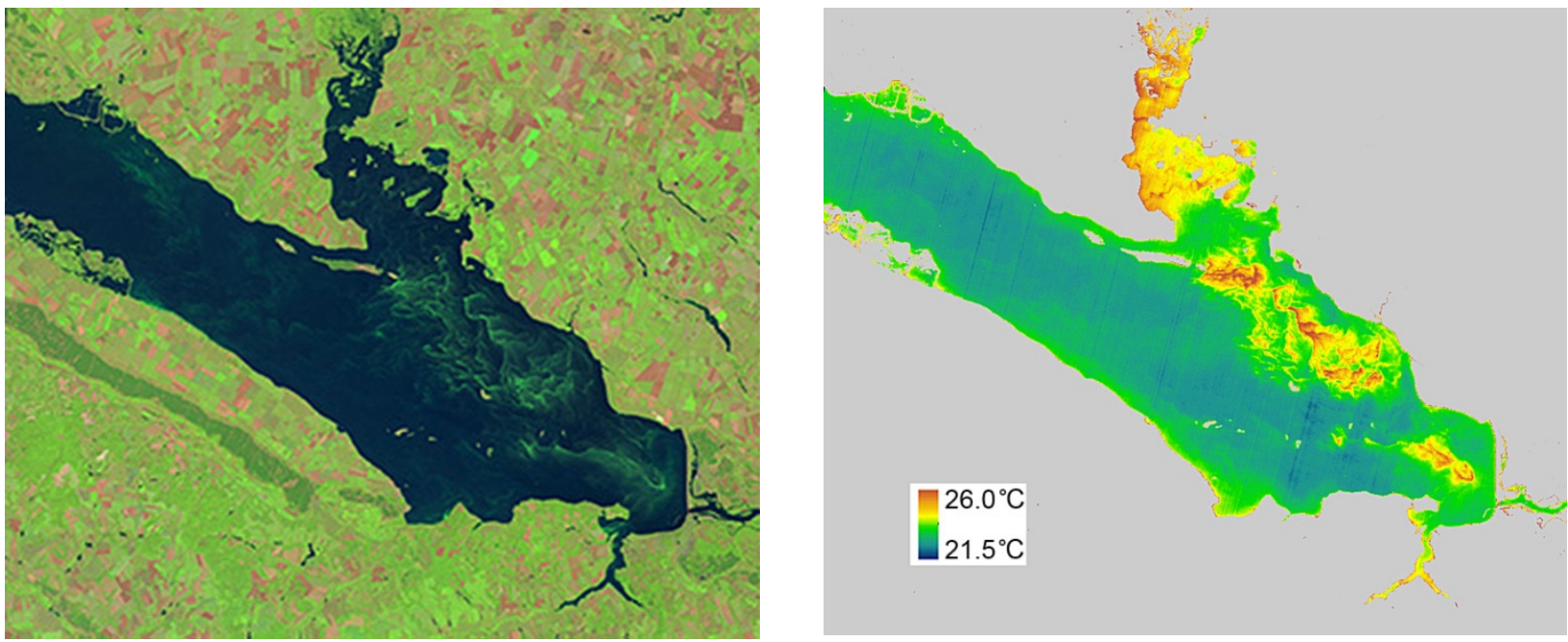

Fig. 11. The algal boom (on the left) and water temperature in the Kremenchutske Reservoir dated 19.08.2017.
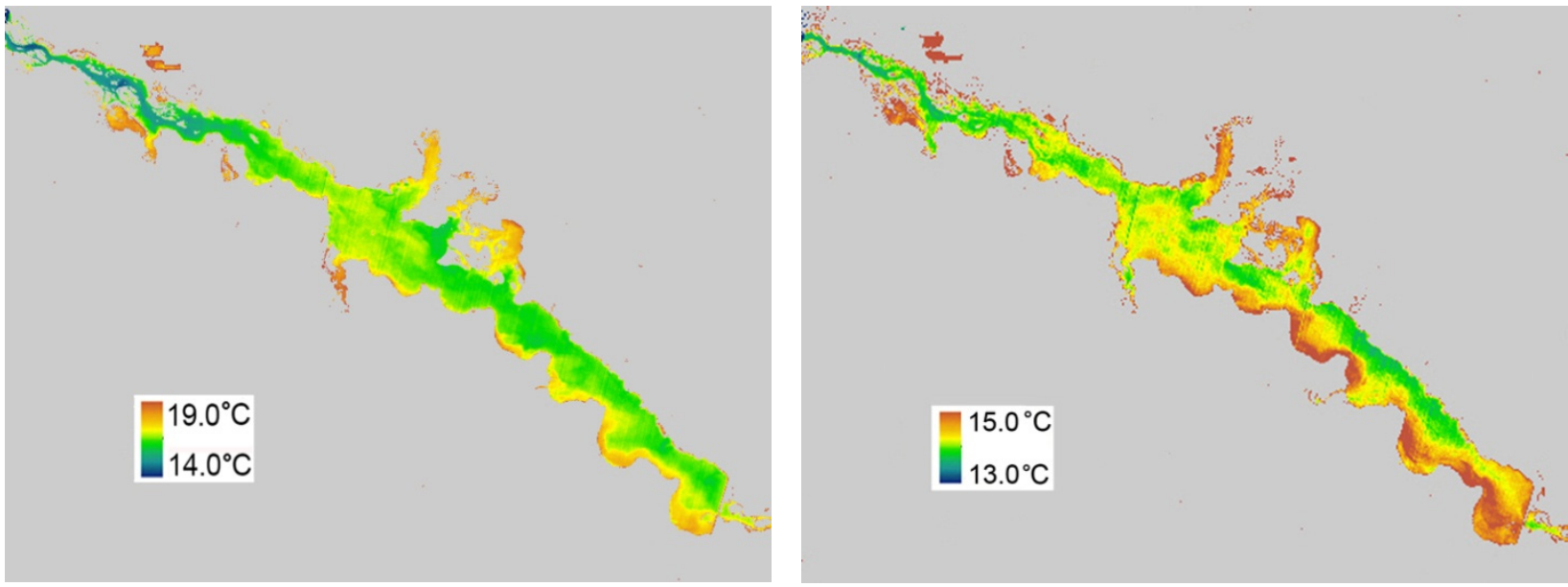

Fig. 12. Water temperature in the surface layer of the Kamianske Reservoir: on the left - dated 11.05.2018, on the right - dated 18.10.2018.
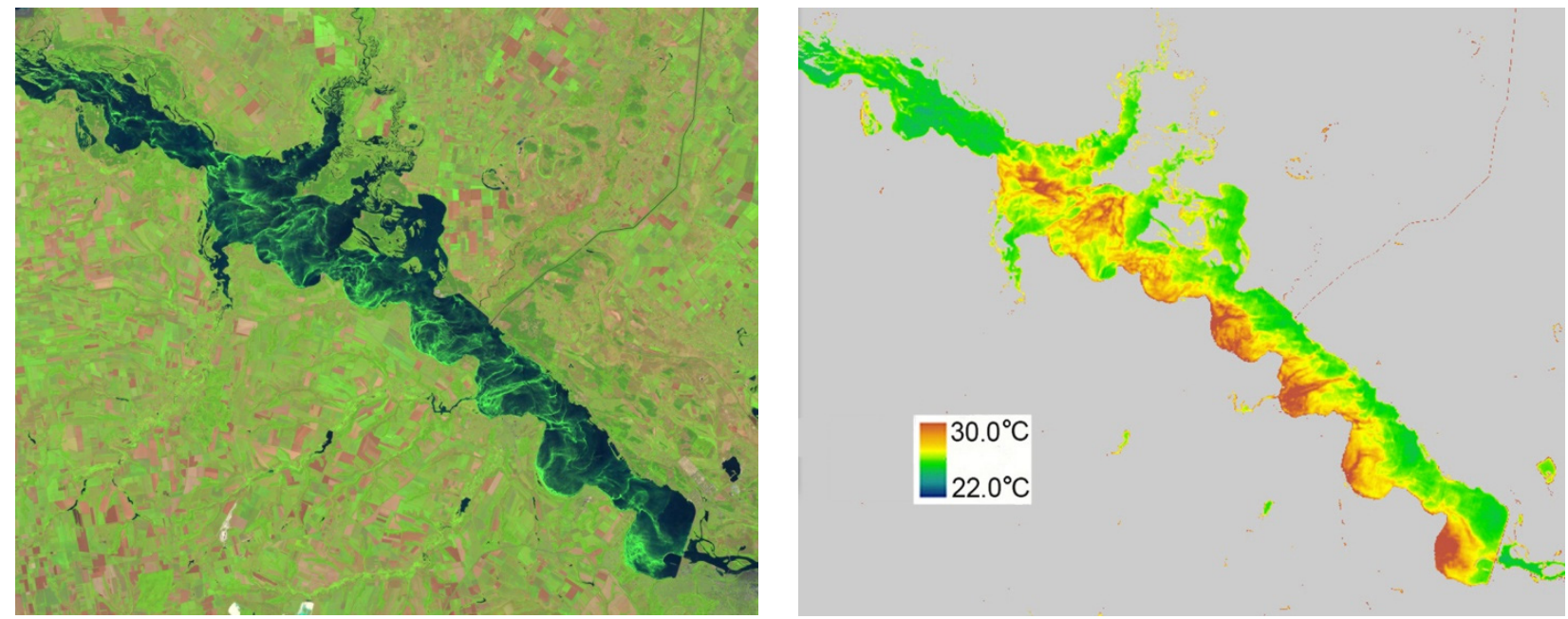

Fig. 13. Correspondence between algal bloom and water temperature in the surface layer of the Kamianske Reservoir, dated 12.08.2017.

In some satellite images (for example, August 20, 2014) of the water area you can see a narrow strip left by a large ship. The water temperature inside this stripe is lower than nearby, which is caused by the water exchange (Fig. 14).

Comparing the images in Fig. 14, the difference in the spa- tial resolution of the bands in the optical range of the spectrum $(30 \mathrm{~m})$ and the thermal B10 $(100 \mathrm{~m})$ should be taken into account. As a result, the ship's stripe in the image of natural colors becomes clearer than the stripe in the image that shows the water temperature. 

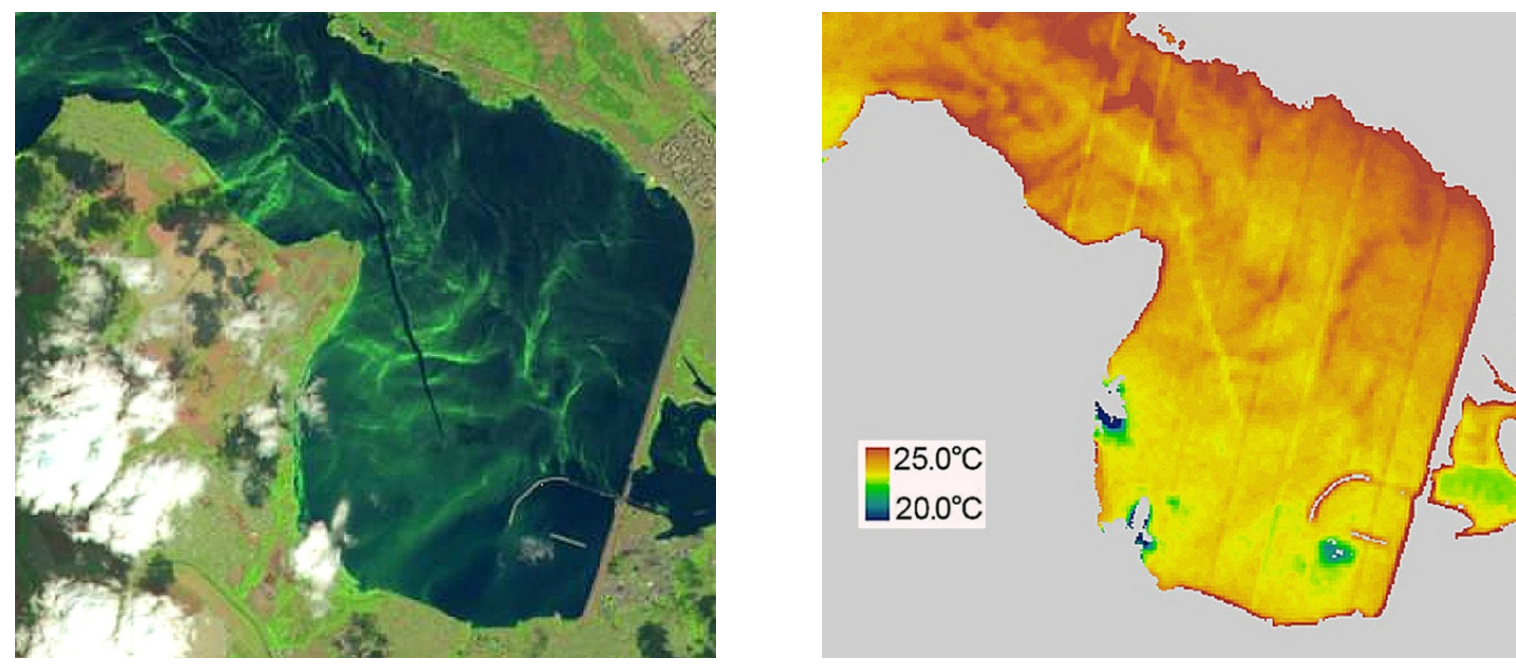

Fig. 14. The trail of ship on the water surface layer of the Kamianske Reservoir (left) and on its thermal image on 20.08.2014.
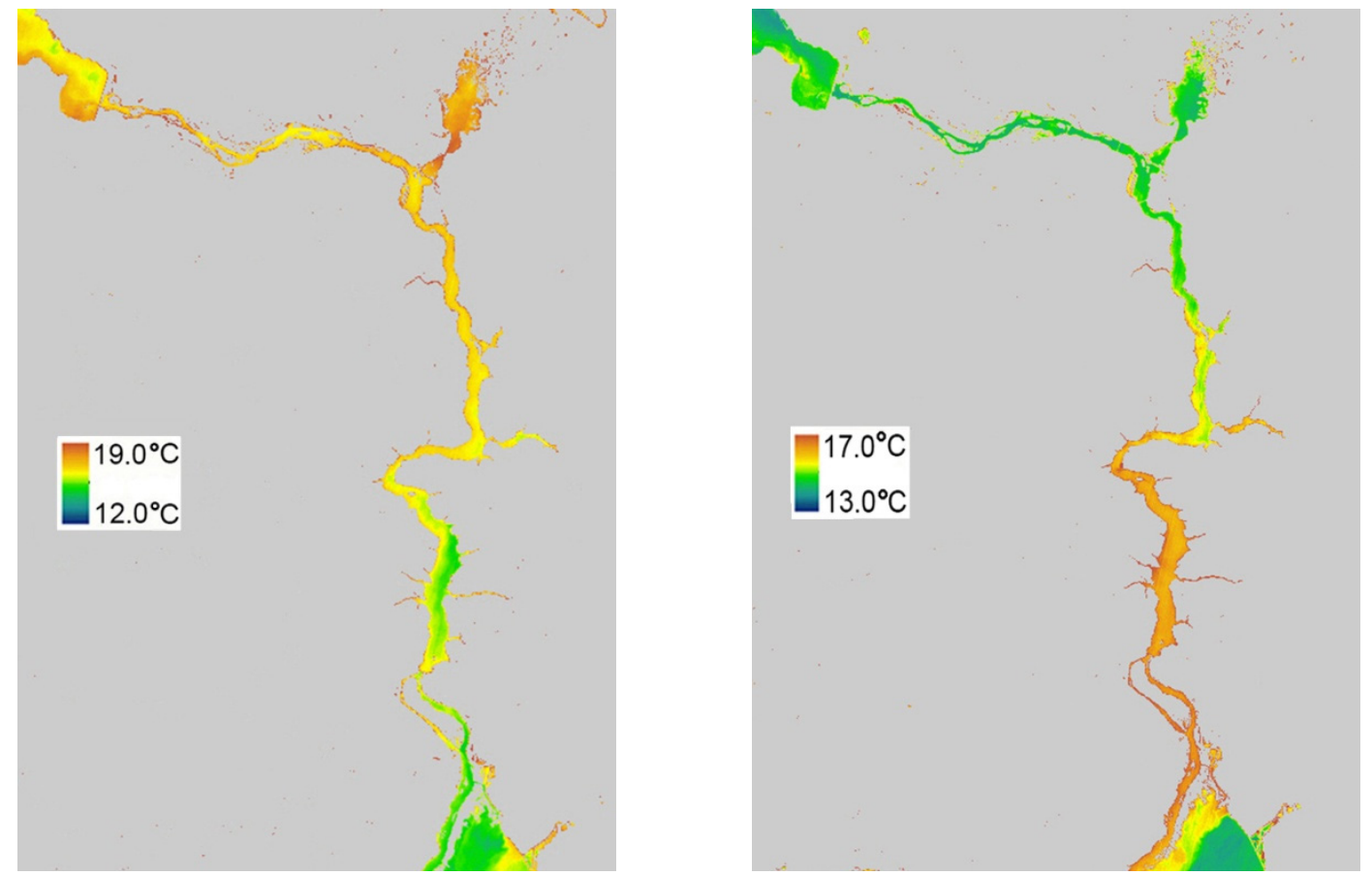

Fig. 15. The water temperature in the surface layer of the Dniprovske Reservoir: on the left - dated 11.05.2018, on the right - dated 18.10.2018

\section{Dniprovske Reservoir}

This reservoir, among others, is the narrowest and the deepest. Another feature of the reservoir is the essential impact of some industrial enterprises, mainly located in Dnipro and Kamianske towns, which is more evident in the cold season. Among these enterprises, there are some thermal power plants and metallurgical ones, which use a large volume of water for their operation. One more feature of the reservoir is the presence of so-called Samara Bay, located in the north-eastern part of the reservoir. The water temperature in this shallow bay in the cold season is the lowest. The longest duration of ice cover is also observed in this bay (Vyshnevskyi and Shevchuk, 2020). But at the end of spring and in summer the highest temperature which reaches $30^{\circ} \mathrm{C}$, is observed in this shallow bay. The highest water temperature in autumn is observed in the deep south- ern part of the reservoir, which remains without ice till the end of December (Fig. 15).

The data of regular monitoring proves these features as well. In October and November the water temperature in the southern part near Zaporizhzhia town is about $2{ }^{\circ} \mathrm{C}$ higher than in the northern and north-western parts of the reservoir.

\section{Kakhovske Reservoir}

The southernmost location of the Kakhovske reservoir is one of the features that affect its water temperature. Another important factor is the large size of the reservoir, which is 5.5 times larger by volume than the Dniprovske one, located upstream. It is important that the north-eastern part of the reservoir is much shallower and wider than the other part adjacent to HPP. The water depth of the north-eastern part is mainly less 

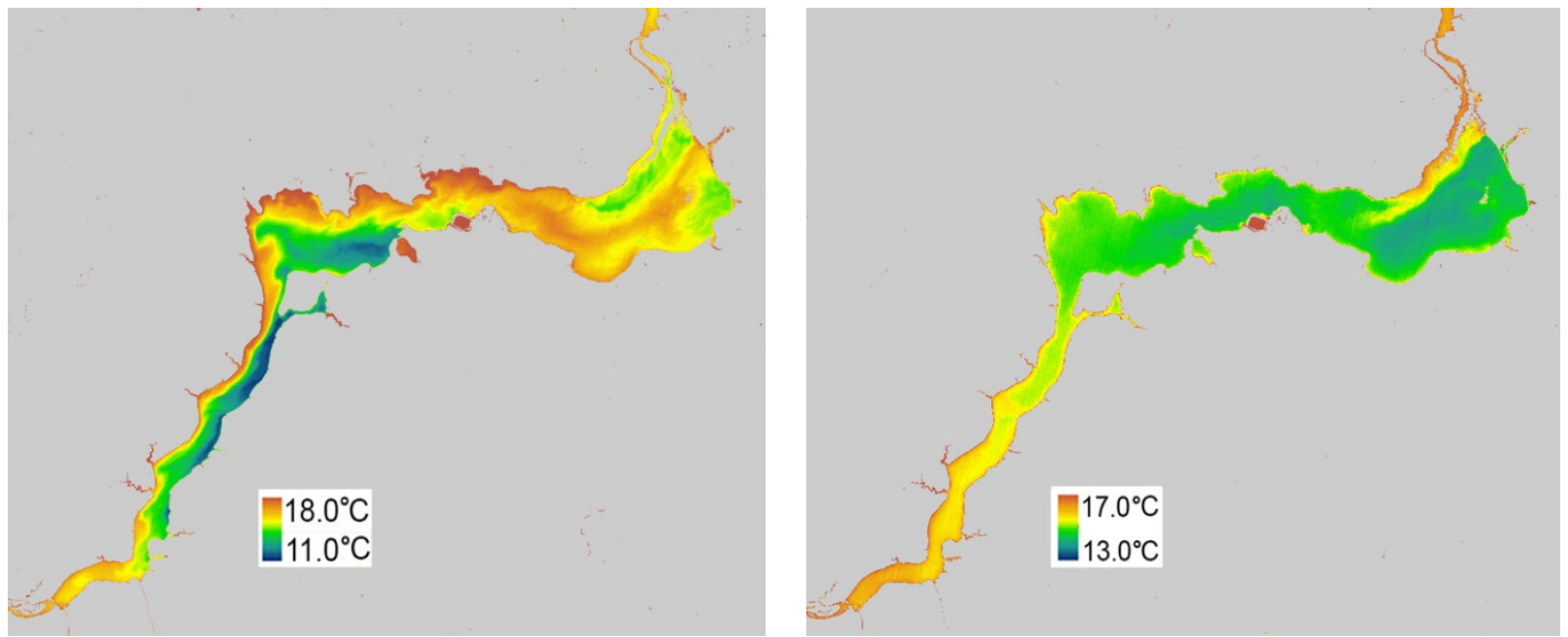

Fig. 16. The water temperature in the surface layer of the Kakhovske Reservoir influenced by wind activity: above - dated 11.05.2018, below - dated 18.10.2018.

than $2 \mathrm{~m}$. The average depth of the southern-western part reaches $10 \mathrm{~m}$. In total, the mean depth of this reservoir is almost the same as that of the Dniprovske one, located upstream. The large length of the reservoir, which exceeds $200 \mathrm{~km}$, also causes some differences in climatic conditions. It mainly concerns the cold season - in the north-eastern part it is colder than in the south-western part.

The great differences in conditions, particularly in water depth in the different parts of the Kakhovske Reservor, cause differences in its thermal regime. Water temperature of the surface layer in the north-eastern part of the reservoir, which is shallow, in April-July is higher than in the south-western part. The situation changes only in August, when the water temperature is the highest $-23.0-24.0^{\circ} \mathrm{C}$. Starting from September, water temperature in the south-western part of the reservoir, where Nova Kakhovka station is located, becomes much higher, than in the north-eastern part. The difference in November reaches $3-4^{\circ} \mathrm{C}$

The relatively cold water in spring and June is the reason for late fish spawning, which is even later than in the reservoirs located upstream.

The essential influence on the water temperature of the Kakhovske Reservoir has the wind. First of all, its speed in the south of Ukraine is larger than in the north. The largest recurrence has the wind from the east. That is why in many cases, the warm water of the surface layer is moved by wind to the south-western part of the reservoir. The cases when the difference in water temperature in the different parts of the reservoir exceeded $5-6{ }^{\circ} \mathrm{C}$ have been observed. It mainly occurs in the autumn season. In May and June, it is also possible in the deep south-western part of the reservoir. The main reason for this is the great difference of water temperature in the surface and bottom layers (Fig. 16).

Relatively warm water remains in the south-western part of the reservoir till the beginning of January. In warm winters, the ice cover in the area adjacent to Kakhovska HPP is not formed.

\section{CONCLUSION}

The use of regular monitoring data at the hydrological stations and remote sensing data enables us to characterize the features of water temperature of the Dnipro Reservoirs.

A common feature of these reservoirs is the tendency to increase the water temperature. In the period 1977-2020, the water temperature in the summer season increased at a rate of about $0.74{ }^{\circ} \mathrm{C}$ decade $^{-1}$, and during May-October about $0.65{ }^{\circ} \mathrm{C}$ decade $^{-1}$.

The thermal regime of the reservoirs is significantly affected by the reservoirs, located upstream. In spring, all the Dnipro Cascade reservoirs, except Kyivske one, have the largest increase of temperature in their central parts. At this time, the discharge of cold water from the lower layer of the reservoirs located upstream significantly affects the temperature of the upper part of reservoirs. Simultaneously, the lower and deep part of the reservoirs remains cold due to the rather slow heating of large water masses. In autumn, mainly from October, the highest water temperature is observed in the lower part of the reservoirs, where large heat reserves.

Climate, weather conditions and algal bloom also have some influence on water temperature. The domination of north-eastern wind over the Kamianske Reservoir in the summer season causes the formation of the areas of high temperature and intensive algal bloom near the south-western right bank of the reservoir. In turn, the domination of east wind over the Kakhovske Reservoir causes the movement of water from the surface layer to the south-western part of the reservoir. As a result, in autumn the water temperature in this south-western part can be $5-6{ }^{\circ} \mathrm{C}$ higher than in the opposite north-eastern part.

The algal bloom that occurs in the reservoirs in the warm season, also affects the water temperature. This phenomenon is accompanied by a decrease in water transparency and the absorption of heat mainly by a thin surface layer.

\section{REFERENCES}

Adrian, R. at al., 2009. Lakes as sentinels of climate change. Limnol. Oceanogr. Nov., 54, 6, 2283-2297. https://aslopubs. onlinelibrary.wiley.com/doi/abs/10.4319/lo.2009.54.6_part_ 2.2283

Austin, J.A., Colman, S.M., 2007. Lake Superior summer water temperatures are increasing more rapidly than regional water temperature: A positive ice-albedo feed-back. Geophysical Research Letters, 34, 1-5. https://agupubs.onlinelibrary.wiley. com/doi/full/10.1029/2006GL029021

Barsi, J.A., Schott, J.R., Hook, S.J. et al, 2014. Landsat-8 Thermal Infrared Sensor (TIRS) vicarious radiometric calibration. Remote Sens., 6, 11607-11626. https://www. mdpi.com/2072-4292/6/11/11607 
Cheng, Y., Voisin, N., Yearsley, J.R., Nijssen, B., 2020. Reservoirs modify river thermal regime sensitivity to climate change: A case study in the Southeastern United States. Water Resources Research, 56, 6, 1-18. https://doi.org/10. 1029/2019WR025784

Czernecki, B., Ptak, M., 2018. The impact of global warming on lake surface water temperature in Poland - the application of empirical-statistical downscaling, 1971-2100. Journal of Limnology, 77, 2, 340-348. https://jlimnol. it/index.php/jlimnol/article/view/jlimnol.2018.1707/1417

Efremova, T.V., Palshin, N.I., Belashov, B.Z., 2016. Water temperature in different types of lakes in Karelia under changing climate based on data of instrumental measurements in 19532011. Water Resourses, 43, 402-411. https://link.springer.com/article/10.1134/S0097807816020020

Filatov, N.N. et al., 2014. Climate change impact on the ecosystem of north of European Russia. Scientific Researches of Russian State Hydrometeorological University, No 34, 4855. (In Russian.)

Kopylov, A.I., Lazareva, V.I., Mineeva, N.M. et al., 2012. Influence of anomalous high water temperatures on the development of the plankton community in the Middle Volga Reservoirs in summer 2010. Doklady Biological Sciences, 442, 11-13. $\quad$ https://www.researchgate.net/pro file/Valentina-Lazareva/publication/221715635_Influence_ of_anomalous_high_water_temperatures_on_the_developme nt_of_the_plankton_community_in_the_Middle_Volga_rese rvoirs_in_summer_2010/links/541176b90 0 cf264cee28b35fe/ Influence-of-anomalous-high-water-temperatures-on-the-de velopment-of-the-plankton-community-in-the-Middle-Vol ga-reservoirs-in-summer-2010.pdf

Lieberherr, G., Wunderle, S., 2018. Lake surface water temperature derived from 35 years of AVHRR Sensor Data for European lakes. Remote Sens., 10, 7, 990, 1-25. https://www.mdpi.com/2072-4292/10/7/990

Litvinov, A.S., Zakonnova, A.V., 2012. Thermal regime in the Rybinsk Reservoir under global warming. Russian Meteorology and Hydrology, No 9, 640-644. https://link.springer.com/article/10.3103/S1068373912090087

Marszelewski, W., Pius, B., 2016. Long-term changes in temperature of river waters in the transitional zone of the temperate climate: A case study of Polish rivers. Hydrol. Sci. J., 61, 1430-1442. https://www.tandfonline.com/doi/full/10. $1080 / 02626667.2015 .1040800$

Meilutyte-Barauskiene, D., Kovalenkoviene, M., Sarauskiene, D., 2005. The impact of runoff regulation on the thermal regime of the Nemunas. Environmental Research, Engineering and Management, 4, 34, 43-50. https://www. researchgate.net/profile/Diana-Meilutyte-Lukauskiene/pub lication/266340509_The_Impact_of_Runoff_Regulation_on the Thermal_Regime_of_the_Nemunas/links $/ 54 \mathrm{dc} 540 \overline{\mathrm{b} 0} 0 \mathrm{cf}$ $\overline{2}$ a7769d95c521/The-Impact-of-Runoff-Regulation-on-theThermal-Regime-of-the-Nemunas.pdf

Nowak, B.M., Ptak, M., Stanek, P., 2020. Influence of a lake on river water thermal regime: a case study of Lake Sławianowskie and the Kocunia River (Pomeranian Lakeland, Northern Poland). Meteorology, Hydrology and Water Management, 8, 1, 78-83. http://yadda.icm.edu.pl/yadda/element/bwmeta1.el ement.baztech-252376b0-d887-4b2c-be93-18b2b18d5930

Pareeth, S. et al., 2017. Warming trends of perialpine lakes from homogenised time series of historical satellite and in-situ data. Science of the Total Environment, 578, 417-426. https://www.sciencedirect.com/science/article/abs/pii/S0048 969716323907
Ptak, M., Sojka, M., Choinski, A., Nowak, B., 2018. Effect of environmental conditions and morphometric parameters on surface water temperature in Polish lakes. Water, 10, 580, 119. https://www.mdpi.com/2073-4441/10/5/580

Ptak, M., Sojka, M., Nowak, B., 2020. Effect of climate warming on a change in thermal and ice conditions in the largest lake in Poland - Lake Sniardwy. J. Hydrol. Hydromech., 68, 3, 260-270. http://www.uh.sav.sk/Portals/16/vc_articles/ 2020_68_3_Ptak_260.pdf

Schaeffer, B.A., Iiames, J., Dwyer, J. et al., 2018. An initial validation of Landsat 5 and 7 derived surface water temperature for U.S. lakes, reservoirs, and estuaries. International Journal of Remote Sensing, 39, 7789-7805. https://www.tandfonline.com/doi/full/10.1080/01431161.20 18.1471545

Sharaf, N. et al., 2019. Lake surface temperature retrieval from Landsat- 8 and retrospective analysis in Karaoun Reservoir, Lebanon. Journal of Applied Remote Sensing, 13, 4, 1-14. https://www.spiedigitallibrary.org/journals/journal-of-appli ed-remote-sensing/volume-13/issue-4/044505/Lake-surfacetemperature-retrieval-from-Landsat-8-and-retrospective-ana lysis/10.1117/1.JRS.13.044505.full?SSO=1

Strutynska, V.M., Grebin, V.V., 2010. Thermal and ice regime of the Dnipro River basin rivers from the second half of the twentieth century. Kyiv: Nika-Center, 196 p. (In Ukrainian.) Vyshnevsky, V.I., 2020a. Hydrological and hydrochemical regime of the Dnieper Reservoirs. Hydrobiological Journal, 56, 4, 103-120, http://www.dl.begellhouse.com/journals/38 cb2223012b73f2,4923ebe16bbd8a7a,7cc30384093cba4a.html

Vyshnevskyi, V.I., 2020b. Temperature and ice regimes of waterbodies under the impacts of global warming and a hydropower plant. Meteorology, Hydrology and Water Management, 2, 38-45. http://yadda.icm.edu.pl/baztech/element/ bwmeta1.element.baztech-6f5b27a9-21a6-4b05-935d-53938 $6181 \mathrm{f} 99$

Vyshnevskyi, V.I., Shevchuk, S.A., 2018. Use of remote sensing data for study of water bodies of Ukraine. Kyiv: Interpres LTD, 84 p. (In Ukrainian.)

Vyshnevskyi, V.I., Shevchuk, S.A., 2020. Use of remote sensing data to study ice cover in the Dnipro Reservoirs. Journal of Geology, Geography and Geoecology, 29, 1, 206-216, https://geology-dnu.dp.ua/index.php/GG/article/view/677

Wang, Y., Zhang, N., Wang, D., Wu, J., 2020. Impacts of cascade reservoirs on Yangtze River water temperature: Assessment and ecological implications. Journal of Hydrology, 590, 1-10. http://hpkx.cnjournals.com/uploadfile/news_ima ges/hpkx/2020-08-20/1-s2.0-S0022169420307009-main.pdf

Woolway, R.I., Dokulil, M.T., Marszelewski, W. et al., 2017. Warming of Central European lakes and their response to the 1980s climatic regime shift. Climate Change, 141, 759-773. https://link.springer.com/content/pdf/10.1007/s10584-0171966-4.pdf

Zhao, J., Li, H., Cai, X. et al., 2020. Long-term (2002-2017) impacts of Danjiangkou dam on thermal regimes of downstream Han River (China) using Landsat thermal infrared imagery. Journal of Hydrology, 589, 125135. https://www.sciencedirect.com/science/article/abs/pii/S0022 169420305953

Received 18 March 2021 Accepted 7 June 2021 